\title{
Attitude and Practice toward Delivering of Verbal Postoperative Instructions by Undergraduates and Trainees: A Descriptive Study
}

\author{
${ }^{1}$ Aisha Wali, ${ }^{2}$ Talha M Siddiqui, ${ }^{3}$ Aisha Shamim, ${ }^{4}$ Tabass um Majeed, ${ }^{5}$ Miran Khan
}

\begin{abstract}
Introduction: Dentists' knowledge and attitudes toward oral health concern provides the structure for their professional work and should be able to convey evidence-based knowledge of oral healthcare to the community. The delivery of safe and appropriate care and instructions to patients is of prime importance to dental professionals.
\end{abstract}

Materials and methods: A cross-sectional study was conducted for analysis of attitude and practice toward delivering of postoperative instructions by undergraduates and trainees. A cluster sampling technique was used and 220 forms were distributed in five dental institutes of Karachi. Two hundred forms were fully filled and returned. Students of final year and house surgeons were included in the study. Data were statistically analyzed for frequencies and percentages with Chi-square test using SPSS version 19.

Results: The result of the present study reported that $124(62 \%)$ of the respondents informed the patients that how long the anesthesia will last and numbing wears off. One hundred and eleven $(55.5 \%)$ of the respondents delivered verbal postoperative instructions after amalgam restoration and 127 (63.5\%) after composite restorations. One hundred and thirty-one (65.5\%) of the respondents informed patients about temporary filling materials. One hundred and twenty-two (61\%) of the respondents delivered the verbal instructions after placing a post or doing core build-ups. Ninety-nine (49.5\%) of the respondents verbally explained the importance of full coverage crown.

Conclusion: The present study concluded that majority of the students and trainees are lacking in uttering the required postoperative instructions after restorative treatment.

Keywords: Local anesthesia, Postoperative instructions, Postoperative sensitivity.

How to cite this article: Wali A, Siddiqui TM, Shamim A, Majeed T, Khan M. Attitude and Practice toward Delivering of Verbal Postoperative Instructions by Undergraduates and Trainees: A Descriptive Study. World J Dent 2015;6(2):71-76.

Source of support: $\mathrm{Nil}$

Conflict of interest: None

${ }^{1}$ Senior Lecturer, ${ }^{2}$ Associate Professor, ${ }^{3-5}$ House Surgeon

${ }^{1-5}$ Department of Operative Dentistry, Baqai Dental College Baqai Medical University, Karachi, Pakistan

Corresponding Author: Aisha Wali, Senior Lecturer, Department of Operative Dentistry, Baqai Dental College, Baqai Medical University, Karachi, Pakistan, Phone: 03002248518, e-mail: aishawali@ hotmail.com

\section{INTRODUCTION}

Dentists' knowledge and attitudes toward oral health concern provides the structure for their professional work and should be able to convey evidence-based knowledge of oral healthcare to the community. ${ }^{1}$ Appropriate utilization of dental care services is still dubious in most of the developing nations. ${ }^{2}$ The delivery of safe and appropriate care and instructions to patients is of prime importance to dental professionals. ${ }^{3}$ Both the dentist and the staff exert a fundamental role in instructing and motivating the patients to perform a frequent and effectiveness oral hygiene. ${ }^{4}$ Garcia et $\mathrm{l}^{5}$ created an education and motivation program in which the patients were periodically instructed on the necessity of periodic recalls to maintain the good oral health achieved. A patient's satisfaction is depended on the likelihood of choosing a dentist, making and keeping dental appointments, and complying with dentists postoperative care and instructions. ${ }^{6-10}$ Researchers from many studies have assessed patients satisfaction with the preventive care received in dental clinics; the generalizability of findings from that dental settings to other practice settings may be questionable. ${ }^{7,10-13}$ Therefore, there is little information provided about satisfaction with dental care among patients who received set of dental treatment. ${ }^{14,15}$ Adequate patient education delivered after dental treatment demonstrated to improve patient satisfaction and decrease postoperative complains. ${ }^{16,17}$ Such education includes delivery of postoperative instructions, medication instructions and advise on home care. Postoperative instructions can be given in verbal and/or written forms. ${ }^{18}$ While the relative benefit of verbal or written instructions have not been clearly established. ${ }^{16,18}$ Previous comparisons of the relative efficacy of the various forms of postoperative instructions reported were common in the medical, pharmaceutical and nursing literature but the dental reports are rare. ${ }^{19}$

The purpose of the present study was to assess the attitude and practice toward delivering of verbal postoperative instructions by undergraduates and trainees.

\section{MATERIALS AND METHODS}

A cross-sectional study was conducted for analysis of attitude and practice toward delivering of postoperative 
instructions by undergraduates and trainees. The study was conducted in the month of January 2014 to March 2014 in the Department of Operative Dentistry, Baqai Dental College and was approved by the Ethical Committee, Baqai Medical University. A cluster sampling technique was used and 220 forms were distributed in five dental institutes of Karachi. Two hundred forms were fully filled and returned (Annexure 1) showed the structured questionnaire based on 10 questions related to verbal instructions given after local anesthesia, composite and amalgam restorations, composite build-ups, temporary restorations, sensitivity to hot and cold liquids and oral

Annexure 1: Survey form for delivering of postoperative instructions

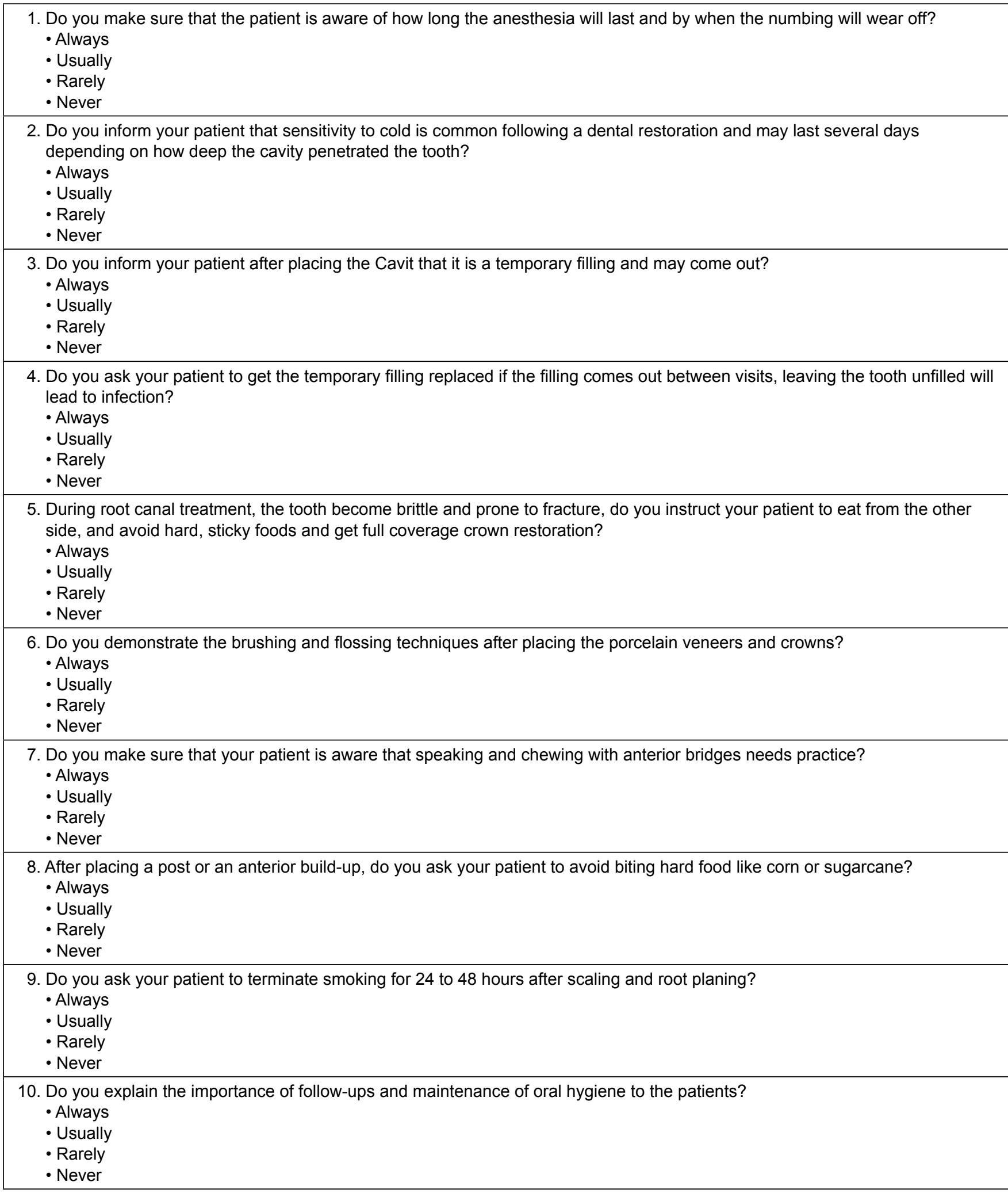


hygiene instructions. Students of final year and house surgeons were included in the study and the dental students of 1st, 2nd and 3rd year, graduates with more than 1 year of clinical experiences were excluded from the study. Data were statistically analyzed for frequencies and percentages with Chi-square test using SPSS version 19.

\section{RESULTS}

The result of the present study reported that 124 (62\%) of the respondents informed the patients that how long the anesthesia will last and numbing wears off. Table 1 shows frequency of the respondents giving verbal instructions about the awareness of anesthesia numbness and postoperative sensitivity after restoration. One hundred and eleven (55.5\%) of the respondents delivered verbal postoperative instructions after amalgam restoration and $127(63.5 \%)$ after composite restorations Table 2 shows frequency of respondents giving verbal instructions after amalgam and composite restorations. One hundred and thirty-one (65.5\%) of the respondents informed patients about temporary filling materials. Table 3 shows frequency of respondents to instruct the patient after temporary restorations. One hundred and twenty-two (61\%) of the respondents delivered the verbal instructions after placing a post or doing core build-ups. Ninety-nine (49.5\%) of the respondents verbally explained the importance of full coverage crown. Table 4 shows frequency of respondents giving instructions after core build-ups and crown placement.

\section{DISCUSSION}

The study emphasized on the overall mode of practice among students of final year students and trainees in relation to the postoperative instructions after a restorative treatment. Since the aim of the study was to assess the frequency of respondents delivering the postoperative instructions after composite restorations, amalgam restoration, post and core build-ups, porcelain crowns and veneers. The result of the present study reported that a majority of final year students and trainees lacked the basic education regarding postoperative instructions after the restorative treatments. Up till now, no study on attitude and practice toward delivering of verbal postoperative instructions by undergraduates and trainees has been carried out, the nature and frequency of following the right pattern is unknown.

Local anesthesia administered by the infiltration route is considered to be highly effective in producing clinical anesthesia in normal tissue. ${ }^{20}$ Although nerve-block injections are more technically difficult, and, therefore, somewhat less predictable than infiltration injections. ${ }^{21-27}$ However, regardless of the type of local anesthetic used, postoperative soft-tissue anesthesia may lasts for several hours. ${ }^{28,29}$ Following a dental appointment requiring local anesthesia of the lower teeth, patient may inadvertently bite the lower lip out associated with the unfamiliar sensation of being numb or because no pain is felt. ${ }^{30,31}$ One hundred and twenty-four (62\%) of the respondents always delivered postoperative verbal instructions about the duration of local anesthesia wearing off and

Table 1: Frequency of the respondents giving verbal instructions about the awareness of anesthesia numbness and postoperative sensitivity after restoration

\begin{tabular}{lcccc}
\hline Questionnaire & Always & Usually & Rarely & Never \\
\hline $\begin{array}{l}\text { Do you make sure that the patient is } \\
\text { aware of how long the anesthesia will }\end{array}$ & $124(62 \%)$ & $74(37 \%)$ & $2(1 \%)$ & $0(0 \%)$ \\
$\begin{array}{l}\text { last and by when the numbing will wear } \\
\text { off? }\end{array}$ & $128(64 \%)$ & $70(35 \%)$ & $2(1 \%)$ & $0(0 \%)$ \\
$\begin{array}{l}\text { Do you inform your patient that } \\
\text { sensitivity to cold is common following }\end{array}$ & & & \\
$\begin{array}{l}\text { a dental restoration and may last few } \\
\text { days depending on how deep the cavity } \\
\text { penetrated the tooth? }\end{array}$ & & & \\
$\begin{array}{l}\text { Do you explain the importance of follow- } \\
\text { ups and maintenance of oral hygiene to } \\
\text { the patients? }\end{array}$ & $79(39.5 \%)$ & $77(38.5 \%)$ & $42(21 \%)$ & $2(1 \%)$ \\
\hline
\end{tabular}

Table 2: Frequency of respondents giving verbal instructions after amalgam and composite restorations

\begin{tabular}{lllll}
\hline & Always & Usually & Rarely & Never \\
\hline $\begin{array}{l}\text { Do you instruct your patient after a } \\
\text { composite restoration to avoid water and }\end{array}$ & $127(63 . \%)$ & $72(36 \%)$ & $1(0.5 \%)$ & $0(0 \%)$ \\
$\begin{array}{l}\text { fizzy drinks for next 4 hours? } \\
\begin{array}{l}\text { Do you instruct your patient not to use } \\
\text { the quadrant restored with amalgam for }\end{array}\end{array}$ & $111(55.5 \%)$ & $88(44 \%)$ & $1(0.5 \%)$ & $0(0 \%)$ \\
almost 24 hours? & & & & \\
\hline
\end{tabular}


Table 3: Frequency of respondents to instruct the patient after temporary restoration

\begin{tabular}{lllll}
\hline & Always & Usually & Rarely & Never \\
\hline $\begin{array}{l}\text { Do you inform your patient after placing } \\
\text { Cavit that it is a temporary filling and } \\
\text { may come out? }\end{array}$ & $126(63 \%)$ & $72(32 \%)$ & $2(1 \%)$ & $0(0 \%)$ \\
$\begin{array}{l}\text { Do you ask your patient to get the } \\
\text { temporary filling replaced if the filling } \\
\text { comes out between visits, leaving the } \\
\text { tooth unfilled will lead to infection? }\end{array}$ & $131(65.5 \%)$ & $62(31 \%)$ & $7(3.5 \%)$ & $0(0 \%)$ \\
\hline
\end{tabular}

Table 4: F requency of respondents giving instructions after core build-ups and crown placement

\begin{tabular}{llll}
\hline & Always & Usually & Rarely \\
\hline $\begin{array}{l}\text { After placing a post or an anterior build-up, } \\
\text { do you ask your patient to avoid biting hard } \\
\text { food like corn or sugarcane? }\end{array}$ & $122(61 \%)$ & $78(39 \%)$ & $0(0 \%)$ \\
$\begin{array}{l}\text { During RCT, the tooth become brittle and } \\
\text { prone to fracture, do you instruct your patient } \\
\text { to eat from the other side, and avoid hard, }\end{array}$ & $99(49.5 \%)$ & $101(50.5 \%)$ & $0(0 \%)$ \\
$\begin{array}{l}\text { sticky food and get full coverage crown } \\
\text { restorations? }\end{array}$ & & & \\
$\begin{array}{l}\text { Do you demonstrate brushing and flossing } \\
\text { technique after placing a porcelain crown? }\end{array}$ & $120(60 \%)$ & $79(39.5 \%)$ & $1(0.5 \%)$ \\
\hline
\end{tabular}

numbness lasting followed by 74 (37\%) usually and 2 (1\%) of the respondents rarely delivered instructions.

Postoperative sensitivity after tooth-colored composite restoration remains a challenge and was reported in several studies to be up to one-third of the study sample. ${ }^{32}$ Despite of great advancements in technology of materials and adhesive systems, postoperative sensitivity occured if the dental practioner is not aware of both the placement and bonding technique required in direct composite restorations. ${ }^{33}$ Persistent postoperative sensitivity after composite placement may track the following mechanism of action of polymerization shrinkage that forms a gap under the restoration, which is filled with dentinal fluid within the first 24 to 36 hours. When a particular tooth is subjected to either hot or cold stimulus, fluid contraction and expansion in occurred in the gaps, which causes fluid movement within the dentinal tubules that leads to postoperative sensitivity. ${ }^{34}$ One hundred and twenty-seven $(63.5 \%)$ of the respondents always delivered instructions for postoperative sensitivity that water and fizzy drinks should be avoided for 4 hours after a composite restoration, followed by 72 (36\%) usually and $1(0.5 \%)$ rarely.

Postoperative sensitivity following the routine placement of an amalgam restoration continues to be an erratic problem in restorative dentistry. ${ }^{35-37}$ It is usually encountered during the first few days following placement of the restoration, ${ }^{38}$ One hundred and eleven (55.5\%) of the respondents always delivered the instructions about not using amalgam restored quadrant for almost 24 hours after an amalgam restoration, 88(44\%) usually and 1 $(0.5 \%)$ of the respondents rarely delivered instructions for postoperative sensitivity. One hundred and twenty-eight (64\%) of the respondents delivered verbally that sensitivity to cold following restorations is common and may last few days depending on the depth of the cavity. Fahad $\mathrm{U}$ et al in 2010 conducted a research that concluded that restorations placed with the soft start curing technique reduces sensitivity. ${ }^{39}$

Temporary fillings done in root canal treatment or before completion of the final restorations, they provide a barrier against salivary contamination of the root canal. Intermediate restorative material (IRM) and Cavit are commonly used as temporary filling materials. ${ }^{40}$ Intermediate restorative material, that is used due to its high compressive strength, ${ }^{41}$ has been demonstrated in bacterial leakage to be less leak proof than Cavit. ${ }^{42,43}$ Cavit is a temporary filling material that is placed to save the unfilled tooth from infection, only $126(63 \%)$ of the respondents informed verbally that it is a temporary filling material and may gets dislodged, $72(36 \%)$ of the respondents usually instructed their patients. One hundred and thirty-one $(65.5 \%)$ of the respondents always verbally instructed their patients to get the temporary filling done again if it gets dislodged, whereas $62(31 \%)$ of the respondents usually delivered instructions to their patients.

A core build-up is a restoration placed in badly broken down tooth to restore the bulk of the coronal portion of the tooth in order to facilitate subsequent restoration by means of an indirect extracoronal restoration. ${ }^{44,45}$ Compressive and tensile strength of core materials is thought to be important because core usually replace a large bulk of tooth structure and must resist multidirectional forces 
for many years. ${ }^{46,47}$ One hundred and twenty-two (61\%) of the respondents always delivered postoperative instructions that patients should refrain from biting hard food like sugarcane or corn after placing an anterior post or build-up. Seventy-eight (39\%) usually instructed about avoidance to bite hard object.

The long life of endodontically involved teeth has been greatly improved by continuous advancements in endodontic therapy and restorative procedures. It has been reported that a large number of endodontically treated teeth are restored to their original function. ${ }^{48}$ Ninety-nine (49.5\%) of the respondents always verbally explained the importance of full coverage crown after root canal treatment, the tooth becomes brittle and prone to fracture, whereas 101 (50.5\%) of the respondents usually instructed their patients to get full coverage crown done.

Regarding improvements in oral hygiene maintenance in a mouth with rapidly progressing caries or periodontal diseases there is obviously no point in arguing upon a complex course of treatment involving crowns. The first priority must be to stop the cause and arrest the disease process and improve the oral hygiene. Although every effort should be made by both dental practioner and patient to improve bad oral hygiene, there are those who are simply not able to improve, but who are nevertheless fortunate in having a slow rate of progress of periodontal disease and a low caries incidence, and for these patients crowns are often justified. ${ }^{48}$ Seventynine $(39.5 \%)$ demonstrated the brushing and flossing techniques along with the importance of follow-ups and oral hygiene maintenance.

The findings of the study explained the need of educational interventions during undergraduate studies and the trainees should be kept a check and supervised during and after the restorations. They should follow the protocols and plan the treatment accordingly in order to avoid any treatment failure and should make sure that they deliver postoperative instructions verbally as well as written to save the patient from any postoperative complains. ${ }^{49-51}$

\section{CONCLUSION}

The present study concluded that majority of the students and trainees are lacking in uttering the required postoperative instructions after restorative treatment. It is likely that the better postoperative instructions delivered the better will be the postoperative care and lesser are the chances of postoperative complains and failures.

\section{REFERENCES}

1. Ghasemi H, Murtomaa H, Torabzadeh H, Vehkalahti MM. Knowledge of and attitudes towards preventive dental care among Iranian dentists. Eur J Dent 2007;1(4):222-229.

2. Khemka S, Baliga S, Thosar N. Approaches to improve access to dental care services. Int Dent Med J Adv Res 2015;1:1-4.
3. Paul $\mathrm{H}$, William $\mathrm{C}$, Colette $\mathrm{M}$. What is new in governance for conscious sedation in dental practice? Saad Digest 2013;29: 3-8.

4. Bardal PA, Olympio KP, Bastos JR, Henriques JF, Buzalaf MA. Education and motivation in oral health-Preventing diseases and promoting health in patients undergoing orthodontic treatment. Dent Press J Orthod 2011;16:95-102.

5. Garcia PP, Dinelli W, Serra MC. Development of education and motivation program of the patient to the periodic return. Robrac 2000;9:37-40.

6. Ball R. Practical marketing for dentistry, part 3: relationship marketing and patient/customer satisfaction. Br Dent J 1996;180(12):467-472.

7. Gurdal P, Cankaya H, Onem E, Dincer S, Yilmaz T. Factors of patient satisfaction/dissatisfaction in a dental faculty outpatient clinic in Turkey. Community Dent Oral Epidemiol 2000;28(6):461-469.

8. Holt VP, McHugh K. Factors influencing patient loyalty to dentist and dental practice. Br Dent J 1997;183(10):365-370.

9. Thomson WM, Stewart JF, Carter KD, Spencer J. Patient mobility in Australian dentistry. Community Dent Health 1996;13(2):99-104.

10. Williams SJ, Calnan M. Convergence and divergence: assessing criteria of consumer satisfaction across general practice, dental and hospital care settings. Soc Sci Med 1991;33(6):707-716.

11. Handelman SL, Jensen OE, Jensen P, Black PM. Patient satisfaction in a regular and after-hours dental clinic. Spec Care Dentist 1996;16(5):194-198.

12. Chu $\mathrm{CH}$, Yeung $\mathrm{CY}$, Lo EC. Monitoring patient satisfaction with university dental services under two fee-paying systems. Community Dent Oral Epidemiol 2001;29(5):390-398.

13. Alvesalo I, Uusi-Heikkila Y. Use of services, care-seeking behavior and satisfaction among university dental clinic patients in Finland. Community Dent Oral Epidemiol 1984;12(5):297-302.

14. Frank RP, Milgrom P, Leroux BG, Hawkins NR. Treatment outcomes with mandibular removable partial dentures: a population based study of patient satisfaction. J Prosthet Dent 1998;80(1):36-45.

15. Layton D, Walton T. Patient-evaluated dentistry: development and validation of a patient satisfaction questionnaire for fixed prosthodontic treatment. Int J Prosthodont 2011; 24(4):332-341.

16. Blinder D, Rotenberg L, Peleg M, Taicher S. Patient compliance to instructions after oral surgical procedures. Int J Oral Maxillofac Surg 2001;30:216-219.

17. Vallerand WP, Vallerand Ah, Heft M. The effects of postoperative preparatory information on the clinical course following third molar extractions. J Oral Maxillofac Surg 1994;52:1165-1170.

18. Weiner NF, Lovitt R. An examination of patients understanding of information from healthcare providers. Hospital and Community Psychiatry 1984;35:619-620.

19. Shantipriya R, Prasad M, Sanjay K, Sabana K, Krishnanand, Savita S. Assessment of patient remembrance and satisfaction of post surgical instructions: verbal vs verbal and written instructions: a clinical trial. e-Journal of Dentistry 2012;2(4): 246-250.

20. Hargreaves KM, Kaiser K. Local anesthetic failure in endodontics; mechanisms and management. Endod Top 2002; 1:26-39.

21. Guglielmo A, Reader A, Nist R, Beck M, Weaver J. Anesthetic efficacy and heart rate effects of the supplemental 
intraosseous injection of 2\% mepivacaine with 1:20,000 levonordefrin. Oral Surg Oral Med Oral Pathol Oral Radiol Endod 1999;87(3):284-293.

22. Hargreaves KM. Neurochemical factors in injury and inflammation in orofacial tissues. In: Lavigne G, Lund J, Sessle B, Dubner R, editors. Orofacial Pain: Basic Sciences to Clinical Management. Chicago: Quintessence; 2001. p. 45-52.

23. Nakai Y, Milgrom P, Mancl L, Coldwell SE, Domoto PK, Ramsay DS. Effectiveness of local anesthesia in pediatric dental practice. J Am Dent Assoc 2000;131(12):1699-1705.

24. Malamed SF. Handbook of Local Anesthesia. 5th ed. St. Louis: Mosby; 2004. Techniques of Mandibular Anesthesia; p. 227-253.

25. Milles M. The missed inferior alveolar block: a new look at an old problem. Anesth Prog 1984;31:87-90.

26. Moore PA. Pain management in dental practice: tramadol vs codeine combinations. J Am Dent Assoc 1999;130(7):1075-1079.

27. Vinckier F. What is the cause of failure of local anesthesia? Revue Belge Med Dent 2000;55(1):41-50.

28. Hersh EV, Hermann DG, Lamp CJ, Johnson PD, MacAfee KA. Assessing the duration of mandibular soft tissue anesthesia. J Am Dent Assoc 1995;126(11):1531-1536.

29. Pinkham JR, Casamassimo PS, Fields HW, McTigue DJ, Nowak AJ. Pediatric dentistry: infancy through adolescence. 4th ed. Elsevier; 2005.

30. Guideline on appropriate use of local anesthesia for pediatric dental patients. Pediatr Dent 2005;27(Suppl 7):101-106.

31. Haas DA. Localized complications from local anesthesia. J Calif Dent Assoc 1998;26(9):677-682.

32. Akpata ES, Behbehani J. Effect of bonding systems on postoperative sensitivity from posterior composites. Am J Dent 2006;19(3):151-154.

33. Hayashi M, Wilson NH. Failure risk of posterior composites with postoperative sensitivity. Oper Dent 2003;28(6):681-688.

34. Summitt JB. Fundamentals of operative dentistry: a contemporary approach. Chicago: Quintessence Publication; 2006. p. 289-339.

35. Grover P, Hollinger J, Lorton L. A review of the incidence of pain after an operative treatment visit-part I. J Prosthet Dent 1984;51(2):224-225.

36. Johnson G, Gordon G, Bales D. Postoperative sensitivity associated with posterior composite and amalgam restorations. Oper Dent 1988;13(2):66-73.
37. Christensen, G. Preventing postoperative tooth sensitivity in class I, II and V restorations. J Am Dent Assoc 2002;133(2): 229-231.

38. Browning W, Johnson W, Gregory P. Postoperative pain following bonded amalgam restorations. Oper Dent 1997; 22(2):66-71.

39. Fahad U, Farhan R. Postoperative sensitivity in class V composite restorations: comparing soft start vs constant curing modes of LED. J Conser Dent 2011(14):1:76-79.

40. Deveaux E, Hildelbert P, Neut C, Romond C. Bacterial microleakage of Cavit, IRM, TERM, and Fermit: a 21-day in vitro study. J Endod 1999;25(10):653-659.

41. Jendresen MD, Phillips RW, Swartz ML, Norman RD. 'A comparative study of four zinc oxide and eugenol formulations as restorative materials. J Prosthet Dent 1969;21(2): 176-183.

42. Deveaux E, Hildelbert P, Neut C, Boniface B, Romond C. Bacterial microleakage of Cavit, IRM, and TERM. Oral Surg Oral Med Oral Pathol 1992;74(5):634-643.

43. Combe EC, Shaglouf AM, Watts DC, Wilson NH. Mechanical properties of direct core build-up materials. Dent Mater 1999;15(3):158-165.

44. Saygili G, Mahmali SM. Comparative study of the physical properties of core materials. Int J Periodont Rest Dent 2002;22(4):355-363.

45. Nicholls JI. Crown retention-I: stress analysis of symmetric restorations. J Prosthet Dent 1974;31(2):179-184.

46. Yettram AL, Wright KW, Pickard HM. Finite element stress analysis of the crowns of normal and restored teeth. J Dent Res 1976;55(6):1004-1011.

47. Baraban DJ. The restoration of endodontically treated teeth: an update. J Prosthet Dent 1988;59(5):553-558.

48. Smith B, Howe 1. Planning and making crowns. In: Planning and making crowns and bridges. 4th edition. Abingdon, UK: Informa healthcare 2007.

49. Good Practice in the Dental Specialties. Senate of Dental Specialties 2001.Retrieved from www.rcseng.ac.uk/fds.

50. Gomes AP, da Silva EG, Gonçalves SH, Huhtala MF, Martinho FC, Gonçalves SE, Torres CR. Relationship between patient's education level and knowledge on oral health preventive measures. Int Dent Med J Adv Res 2015;1:1-7.

51. Khemka S, Baliga S, Thosar N. Approaches to improve access to dental care services. Int Dent Med J Adv Res 2015;1:1-4. 